\title{
QUALITY OF UNIVERSITY MANAGEMENT AND ITS IMPACT ON THE LOCAL COMMUNITY
}

\author{
Andrey Belov ${ }^{1}$, Galina Chernova ${ }^{2}$, Vladimir Khalin ${ }^{3}$, Natalia Kuznetsova ${ }^{4}$, Larisa Belinskaja \\ ${ }^{1}$ Prof. Dr. Fukui Prefectural University (Japan). Matsuoka-Kenjojima 4-1-1, Eiheiji, Fukui, 910-1195, \\ Japan.Tel.+81-776-61-6000.E-mailabelov@fpu.ac.jp \\ ${ }^{2}$ Prof. Dr. Saint-Petersburg State University. Chaikovskii str., 62-191123, Saint-Petersburg, Russia. E- \\ mail chernovagalina@yandex.ru \\ ${ }^{3}$ Prof. Dr. Saint-Petersburg State University. Chaikovskii str., 62-191123, Saint-Petersburg, Russia. E- \\ mailvhalin@yandex.ru \\ ${ }^{4}$ Prof. Dr. Saint-Petersburg State University. Chaikovskii str., 62-191123, Saint-Petersburg, Russia. E- \\ mail nataliakuz2010@yandex.ru \\ ${ }^{5}$ Prof. Dr. Vilnius University, Sauletekio str. 9, II bld. LT 10222, Vilnius, Lithuania \\ E-mail: larisa.belinskaja@evaf.vu.lt
}

Received 2102 2020, Accepted 19052020

The quality of university management depends on numerous factors, including the consequences it has on the local community. While the consequences have numerous and hardly equitable aspects, this article suggests a synthetic model for the assessment of university management, which considers a full range of existing effects. The research methodology is based on the balanced scorecard concept. Verification, using the available empirical data for comparison of two universities, confirms the model's validity. Thus, the article recommends this model for solving a whole range of university management issues, especially in the interaction of higher education entities with outer and inner communities.

Keywords: assessment of management quality, balanced scorecard, model and algorithm for university management quality evaluation, point measurement units, university management, university as a local community center.

JEL Codes: I21, I23.

\section{Introduction}

Effective management is a significant factor in improving the quality of education in all types of institutions, regardless of their level, field of activity, and type of ownership. The importance of optimizing management manifests most clearly in the higher education sector, when universities act as local community centers and perform vital societal functions related to education, research, innovation, regional development, and business activity. The resulting effects must be identified, equitized, and adjusted for managerial decision-making. The importance of this task is particularly pronounced at the regional level, where the complex web of relationships between public and private sectors, the involvement of state and municipal governments, and the existence of multilayered constraints complicate the management process. These considerations predetermine our study of the university's management quality in the framework of its impact on the local community.

This article hypothesizes that it is possible to build a synthetic model, which will take into account a broad spectrum of existing effects, for evaluating the university management. The aim of the study is to identify the relationship between the quality of management and the performance variables needed to build the model.

Copyright (C) 2020. Published by Vytautas Magnus University. This is an open access article distributed under the terms of the Creative Commons Attribution Non-Commercial 4.0 (CC BY-NC 4.0) license, which permits unrestricted use, distribution, and reproduction in any medium provided the original author and source are credited. The material cannot be used for commercial purposes. 
The research methodology utilizes econometric analysis for the formation, ranking, and determination of point values of a balanced scorecard (BSC) and the calculation of the corresponding sub-indices. For this purpose, the following steps were taken: 1) the content of the BSC was created; 2) BSC indicators were ranked by their importance for solving the task; 3) indicators were scaled for the purpose of comparability and translated into point values; 4) the actual point values were determined; 5) the sub-indices were calculated, i.e., quantitative assessments of the quality of management were carried out; and 6) quantitative estimates were expressed in qualitative form.

As a result, this study led to the creation of a workable model for conducting a comprehensive assessment of the university management quality. The overall significance of the model was tested using available information on the employment of professors in different universities. Positive test results indicated that the model was well suited for direct and reverse translation of a quantitative assessment of management effects into a qualitative (verbal) one. Consequently, this model was found to be highly important for improving the quality of university management, especially in areas with a predominance of ripple and indirect effects, i.e., in the interaction of academic entities with regional and local communities' sustainability. We would thus recommend this model for solving a whole range of issues related to the performance of universities in their role as regional development centers. This aspect of academic activity comprises the most promising area for future research on improving the quality of university management as well as its influence on the local communities.

\section{Research results and their explanation \\ 2.1. Problem statement and literature review}

We define university management as the process of planning, organizing, directing, coordinating, and controlling the use of resources in tertiary education entity to achieve organizational goals. Within this framework, the quality of management has two dimensions: the efficiency of resource utilization and the degree of goals achievement. This approach follows the findings of Owlia, Aspinwall, according to which the basic principles of industrial quality management are generally accepted in the education environment, although with certain reservations arising from its complex and dynamic nature (Owlia, Aspinwall, 1996).

The quality of university management and its assessment in the context of management theory has attracted considerable attention in the scientific literature. The Web of Science database by Clarivate Analytics contains 10,365 documents under the "higher education" plus "management quality" keywords (June 5, 2020). The broad classification categories include "Education Research" (2,378 documents) and Management (851), followed by "Medicine General Internal" (714), "Health Care and Service Sciences" (610), and others. Among the educational and managerial research, the most attention is attracted by issues such as the theoretical aspects of education quality in the knowledge economy (Olssen, Peters, 2005, 775 citations), the measurement of efficiency in higher education (Johnes, 2006, 236 citations) and the students' evaluation of e-learning systems (Ozkan, Koseler, 2009, 234 citations).

The literature reviews focused on the specific topic of management quality are provided by Liman (Liman, 2006) and Rosovsky (Rosovsky, 2014). Among the most important issues is the discussion on the ways to compare world's universities (Salmi, 2009), to compile a list of quality indicators (Udam, Heidmets, 2013) and to implement them in various forms of training (Ahamer, 2013). The attention to managerial aspect is most pronounced in the research devoted to the construction of comparable management and research quality assessments (Adler, Harzing, 2009; Vilgats, Heidmets, 2011; Biju, Nair, 2017; Seema, Udam, Mattisen, Lauri, 2017).

The search in the Russian e-library.ru electronic database conducted on June 3, 2020 for "university" and "management" keywords in titles of magazine articles, books, and conference papers returned 348 hits, 131 of which had 1-32 citations. Over $40 \%$ of cited papers deal with management of quality issues, further research areas include strategic management, time management, foreign experience, and other topics. A significant part of Russian language research has long been associated 
with a relatively narrow range of issues, namely, the provision and assessment of specialist training (as summarized in Maslova, Gafforova, 2012). In recent years, Russian scholars have started to turn their attention to a more comprehensive assessment of university activities for improving the management quality (Khalin, Chernova, 2018a; Belov, Chernova, Khalin, Kuznetsova, 2018).

The transition from narrow to comprehensive research appears to reflect a wider understanding in the academic community about the complex nature of universities and their multilateral interaction with society. The theoretical basis of this process was developed following the innovation helical theory, which brings together academic, industrial, governmental and other social actors. In this framework, universities appear to be one of the main drivers of progressive changes in the economy and in society, combining science and education as well as fulfilling the new function of transferring knowledge and technology (Richter, Pakhomova, 2012; Pakhomova, Richter, 2013).

The triple helix model of innovation describes a web of relationships between universities, industry, and the government to strengthen the process of social and economic innovations in a knowledge-based economy (Etzkowitz, Leydesdorff, 1995). Since the late 2000s several authors have started to explore an extension of the model by introducing the public, the community, the environment and other areas in the innovation framework (Carayannis, Campbell, 2009; Galvao, Others, 2019). The created quadruple and quintuple helix models have numerous implications for academic research and policy making, especially in the fields of regional innovation systems, climate change, and sustainable development.

For the purpose of our research, the helix model of innovation provides valuable insights into the interactions between universities and regional economic and social entities. Training specialists, applied research, transfer of knowledge, and other university functions can contribute extensively to local development. In this sense, the helix model closely fits the existing concepts of academia and community collaboration. For instance, a community engagement of universities, which is sometimes mentioned as their "third mission" besides teaching and research (Schuetze, 2012), comprises a wide range of academic and scholarship activities overlapping with the technology transfer in the helix model of innovation (Preece, 2017).

Consequently, one of the most promising ways to increase the regional and innovative significance of educational institutions there is to develop them as Centers of Communities (COC). The COC concept appeared in the post-war USA and initially comprised public general education schools (Calderwood, 2000; Anglin, 2011). However, since the beginning of the 1990s, the concept has spread to regional universities and was applied in several countries in Europe, Asia, and Australia (OECD, 2001). In particular, in Japan, the transformation of public universities into organizers of educational, scientific, innovative, and public activities at the local level has emerged as an important aspect in the reformation of university education and revitalization of the country's depressed regions (Belov, Zolotov, 2014; MEXT, 2019). We can speculate that this particular aspect of public regional universities can play a crucial role in the territorial development of the economies in transition, solving the pressing problems of population outflow, structural adjustment, and agro-industrial development. We use the term local community in its broadest possible sense, to cover both residents of the region where the university is located (outer community) and university employees (inner community). The outer community can be further divided into regional and municipal communities. Regarding the inner community, one should distinguish between technical workers, temporary employees, and permanent professors. The characteristics of local communities depend significantly on the types of university (private or public, educational or research, suburban campus or urban). At each level of the local community, actors form a complex web of aligned interests and generate a large number of related effects. The coordination of these interests and the use of emerging effects is, therefore, among the most important management tasks.

The activities conducted by universities as centers of local communities generate a complex set of interrelated effects (Zimmerman et.al, 2019). Many of these activities do not have an accurate 
quantitative interpretation and can only be evaluated qualitatively (Jacob, Sutin, Weidman,Yeager, 2019). Accordingly, the task of a unified interpretation of quantitative and qualitative assessments arises. A solution to this problem can be found if the experience gained in other areas of management is taken into account. This logic led to the introduction of the above-mentioned concept of a balanced scorecard (BSC). Kaplan and Norton first proposed the concept of BSC in 1992 as a system for measuring the performance of a financial company (Kaplan \& Norton, 1996). Currently, the term BSC is used in both broad and narrow sense (Balanced Scorecard, 2018; Khalin, Chernova, 2018b). Its broad application involves the consideration of BSC within the whole idea of advancement of a particular company, combining its mission, strategic goals, and the corresponding management system to achieve the goals. BSC includes only those indicators that are necessary and sufficient to build a reliable assessment for a company's development within a specific concept.

Leading world universities already have positive examples of the application of BSC in management practice. The University of California, USA, which comprises 10 public universities of the California State, is a vivid example, as it occupies the leading position in global university rankings. In particular, in 2019, the University of California (UC) was represented by 10 out of 10 universities in the Top 500 Shanghai World University Rankings (ARWU): UC, Berkeley - 4th place; UC, Los Angeles - 11; UC, San Diego - 18; UC, San-Francisco - 20; IC, Santa Barbara - 48; UC, Irvine - 80, UC, Davis - 90; UC, Santa Cruz - 101-150; UC, Riverside - 151-200; UC, Merced 401-500 (UCLA, 2019). Higher education institutions in the USA often employ the BSC concept regardless of their size and level of operation (Papenhausens, Einstein, 2006). In the Ibero-America region or in some Islamic countries, this is mostly applied to a larger-scale national establishment (Cifuentes-Madrid, Couture, Llinas-Audet, 2015; Lassoued, 2018).

Among Russian institutions top positions in the ARWU-2019 were occupied by the Moscow State (87), Saint-Petersburg State (301-400), Moscow Institute of Physics and Technology (401-500), and Novosibirsk State (401-500) universities. With regard to strategic management, the high both national and local schools in Russia have not yet implemented the concept of BSC in an allencompassing way. Bearing that in mind, this article discusses the application of BSC in a more limited sense, i.e., for assessing the quality of management for solving a specific university development problem. As an example, we choose the creation of a positive and productive environment for academic activities and utilize the available information on salaries, fringe benefits, and job contracts of university professors. Nevertheless, the authors argue that the constructed model has a universal design and is fully valid and applicable for conducting any other quantitative and qualitative assessments in the managerial process, and above all, for measuring the ripple effects that arise when universities function as local community centers.

\subsection{The general idea of the model for assessing the university management quality on solving of a specific managerial problem}

We will consider the problem of assessing the university management quality for the case when a university has been assigned a specific management task related to the achievement of a certain strategic goal of its development in a certain period. An excellent example of the successful development was provided by Richter, Pakhomova in their analysis of East German universities transition from "traditional" to "modern" education entities (Richter, Pakhomova, 2012, pp.70-75). Following their logic, we find that a university's performance is described by a large set of various indicators. However, for practical purposes only a limited number of them should be used to carry out the assessment of management quality. This fact highlights the necessity for the implementation of BSC. With this tool, the specific indicators can be ranked, sorted by their importance for the solution to the managerial task, and reduced to the appropriate quantity. The significance of these indicators is expressed by the values of their weights, which are usually determined by experts' estimations. To ensure the comparability of indicators describing the solution of the task, it is necessary to convert their values, presented in natural units, into points. The actual 
values of indicators obtained in points (considering their rankings) should be converted into the final quantitative index of the university management quality. In this case, we must employ an appropriate method of minimization/convolution of these indicators. The obtained final scores represent an assessment of the university management quality to achieve a specific strategic goal, which presumes solving the mentioned tasks. It is advisable to consider the final scores as sub-indices, and the final indicator as an integral index of university management quality for achieving the strategic goal of its development. The integral index (quantitative assessment) provides the necessary data to acquire a verbal assessment of the university management quality in solving the particular task under consideration. To obtain it, the construction of interrelated values of verbal evaluation and interval values of a quantitative assessment (interval values of the sub-index) is carried out. This process is referred to as scaling.

Each value of the verbal scale (for example, "the quality of management is poor", "the quality of management is satisfactory", and "the quality of management is good") by the experts or decision makers is assigned the interval quantitative values of the sub-index. Comparison of the sub-index actual value with its interval values of the scale built earlier indicates the interval in which the actual score falls, and the value of the verbal evaluation that corresponds to the specified interval.

\subsection{Management quality assessment algorithm}

The algorithm that implements the management quality assessment model for solving a specific task is a multi-step process. The provided illustration of its application is based on a dataset from the Saint Petersburg State University (SPSU), Faculty of Economics.

Stage I. The formulation of the specific task as the basis for the assessment of university management quality.

Such tasks can include: attraction and retention of best university professors; selection of most capable university undergraduate and graduate students; creation of favorable conditions for hiring, work and academic contracting of university professors, etc. As one possible scenario, we define the specific management task as a provision of favorable conditions for hiring, work and academic contracting of university professors. We consider this task as one of those that meet the achievement of such a strategic goal of university development as the formation of a capable inner community of professors and researchers in the university. Besides, existing literature considers professors' remuneration as one of the most important factors for their productivity (Altbach, 2012). Certainly, administrative policy is only a part of the university management process; however, research methodology is general in nature and can be applied to other stages of management.

Stage 2. Introduction of a balanced scorecard (BSC) to assess the quality of management.

To assess the quality of university management in solving the problem of creating favorable conditions for hiring, work and academic contracts of university professors, the following balanced scorecard is formed:

E.1 - guaranteed amount of monetary reward for the month of the professor's work,

E.2 - guaranteed duration of the professor's academic contract,

E.3 - the size of the professor's classroom load,

E.4 - the level of social support ("social package", or "fringe benefits") for professors.

We concentrate on full professors only because of the availability of internationally comparable data.

Stage 3. Ranking the BSC indicators used to assess the university management quality.

The priority of BSC indicators for solving this task is usually expressed by the values of their weighting coefficients. Indicators presented at stage 2 can be ranked as follows: weighting coefficient 0.4 corresponds to indicator E.1; weighting coefficient 0.3 corresponds to indicator e.2; weighting coefficient 0.2 corresponds to indicator e.3; weighting coefficient 0.3 corresponds to indicator e.4. 
Stage 4. Scaling of: 1) interval values of indicators, expressed in natural units of measurement;2) interval score values of these indicators; 3) verbal evaluation of the management quality in achieving each target.

Under the scaling, which is carried out for the whole set of BSC indicators, one should distinguish between three interrelated scales (table 1).

Table 1. Example of interrelated scales in assessing the quality of management, indicator E.1 - "guaranteed amount of monetary reward for a month of a professor's work"

\begin{tabular}{|l|c|c|c|}
\hline $\begin{array}{c}\text { Scale of values of the } \\
\text { verbal quality assessment } \\
\text { for managing the } \\
\text { indicator }\end{array}$ & $\begin{array}{c}\text { Quality of } \\
\text { management is "bad" }\end{array}$ & $\begin{array}{c}\text { Quality of management is } \\
\text { "satisfactory" }\end{array}$ & $\begin{array}{c}\text { Quality of } \\
\text { management is } \\
\text { "good" }\end{array}$ \\
\hline $\begin{array}{l}\text { Scale of scoring interval } \\
\text { values of the indicator }\end{array}$ & $\begin{array}{c}\text { From } 0 \text { to } 2 \\
{[0 ; 2]}\end{array}$ & $\begin{array}{c}\text { More than } 2 \text { up to } 8 \\
(2 ; 8]\end{array}$ & $\begin{array}{c}\text { More than } 8 \text { up to } 10 \\
(8 ; 10]\end{array}$ \\
\hline $\begin{array}{l}\text { Scale of interval values of t } \\
\text { he indicator }\end{array}$ & $\begin{array}{c}\text { Up to doubled average } \\
\text { monthly salary in the } \\
\text { region }\end{array}$ & $\begin{array}{c}\text { More than doubled average monthly } \\
\text { salary in the region, but not more } \\
\text { than four times bigger than the } \\
\text { average monthly salary in the region }\end{array}$ & $\begin{array}{c}\text { More than four times } \\
\text { the average monthly } \\
\text { salary in the region }\end{array}$ \\
\hline
\end{tabular}

Source: authors' calculations

The goal of scaling is to ensure the comparability and commensurability of the indicators analyzed to assess the management quality on solving the task in question. It is carried out by the transition from the values of the indicator, measured in natural units, to its values, measured in points (for example, on a 10-point system). Scaling establishes the connection of interval values of the studied indicator with the verbal quality assessment of this indicator. We should point out that the inclusion of verbal evaluations in the table is a process of auxiliary nature when the particular indicator under consideration expresses the quality of management.

Stage 5. Determination of the indicators' actual scoring (point) values used to assess the quality of university management. The assessment is based on the scaling performed at stage 4 . In this case, we compare the actual value of the indicator in natural units with its interval boundaries of the corresponding scale of stage 4 of the algorithm. The result of the comparison is the determination of the interval in which this actual value falls. According to this interval, the corresponding interval of scoring is found, and according to the rules stipulated in advance, the specific score value of this indicator is calculated. Table 2 shows an example of obtaining a scoring estimate of the actual quality of management at SPSU by indicator E.1 - "guaranteed amount of monetary remuneration for the month of the professor's work".

Table 2. Example of obtaining a scoring (in point) of actual management quality by the indicator E.1 - "guaranteed amount of monetary reward for the month of work of a professor" (2017)

\begin{tabular}{|l|c|c|c|}
\hline $\begin{array}{c}\text { Scale of scoring interval } \\
\text { values of the indicator }\end{array}$ & $\begin{array}{c}\text { from } \mathbf{0} \text { to } 2 \\
{[\mathbf{0} ; \mathbf{2}]}\end{array}$ & $\begin{array}{c}\text { more than } \mathbf{2} \text { up to 8 } \\
(\mathbf{2} ; \mathbf{8}]\end{array}$ & $\begin{array}{c}\text { more than 8 up to 10 } \\
\mathbf{( 8 ; 1 0 ]}\end{array}$ \\
\hline $\begin{array}{l}\text { Scale of interval values of } \\
\text { the indicator in natural } \\
\text { units }\end{array}$ & $\begin{array}{c}\text { up to doubled } \\
\text { average monthly } \\
\text { salary in the } \\
\text { region }\end{array}$ & $\begin{array}{c}\text { more than doubled average monthly salary } \\
\text { in the region, but not more than four times } \\
\text { bigger than the average monthly salary in } \\
\text { the region }\end{array}$ & $\begin{array}{c}\text { more than four times } \\
\text { the average monthly } \\
\text { salary in the region }\end{array}$ \\
\hline $\begin{array}{l}\text { The actual value of the } \\
\text { indicator in natural units }\end{array}$ & $\begin{array}{c}53,094 \mathrm{Rubles} \\
\text { or } 2,203 \$ \mathrm{PPP}^{1}\end{array}$ & & \\
\hline
\end{tabular}

\footnotetext{
${ }^{1}$ This salary in 2017 amounted to $97.7 \%$ of the average accrued wages in St. Petersburg for the same year (54,353 Rubles). It is significantly lower than $200 \%$, which was stipulated by political promises (Decree of the President of Russia from May 7, 2012, No. 597) and widely considered as an average local middle-class income. The salary in Rubles is converted to international dollars using the purchasing power parity (PPP) conversion factor provided by the World Bank's World Development Indicators (24.1 Rubles to 1 \$ PPP in 2017, http://wdi.worldbank.org/table/4.16).
} 
The guaranteed size of monetary remuneration for a month of a professor at the Faculty of Economics, SPSU in 2017 (53,094 Rubles or 2,203 \$ PPP) is equal to the score corresponding to actual value of this indicator (2). The professors' income can be significantly higher due to remuneration from scientific grants and supplementary employment. According to existing surveys, these sources make a substantial contribution to the gross income of Russian faculty (Androushchak, Yudkevich, 2012). We should note, that the rules for determining a specific score value in natural units are determined by experts, and therefore may differ. The purpose of stage 5 is to obtain scoring (point) actual values of all the BSC indicators used to assess the quality of university management for solving a specific managerial problem, and, if necessary, corresponding verbal estimates. According to the algorithm, the authors got results presented in Table 3.

\section{Table 3. Actual values of the indicators used to calculate the sub-index of the quality of university management for solving the specific problem of creating favorable conditions for hiring, work and academic contracts of university professors at the Faculty of Economics, SPSU (2017)}

\begin{tabular}{|c|c|c|c|}
\hline Indicators & $\begin{array}{l}\text { Actual values in } \\
\text { natural units }\end{array}$ & \begin{tabular}{|c|} 
Actual values of \\
indicators in point \\
units $\left(\mathrm{E}_{\mathrm{i}}^{\mathrm{p}}\right)$ \\
\end{tabular} & $\begin{array}{c}\text { Actual verbal quality assessment } \\
\text { of the management on relevant } \\
\text { indicator }\end{array}$ \\
\hline $\begin{array}{l}\text { Guaranteed amount of monetary } \\
\text { reward for the month of a } \\
\text { professor's work }(\text { E. } 1)^{2}\end{array}$ & $\begin{array}{l}53,094 \text { Rubles } \\
\text { or 2,203 \$ PPP }\end{array}$ & 2 & $\mathrm{Bad}$ \\
\hline $\begin{array}{l}\text { Guaranteed duration of a } \\
\text { professor's academic } \\
\text { contract (E.2) }\end{array}$ & 2.0 years & 2 & $\mathrm{Bad}$ \\
\hline $\begin{array}{l}\text { The size of the professor's } \\
\text { classroom load (E.3) }\end{array}$ & $\begin{array}{c}8 \text { academic hours a } \\
\text { week through the year }\end{array}$ & 6 & Satisfactory \\
\hline $\begin{array}{l}\text { The level of social support (fringe } \\
\text { benefits) of professors (E.4), } \\
\text { points }^{3}\end{array}$ & 3 & 3 & Satisfactory \\
\hline
\end{tabular}

Source: authors' calculations

Stage 6. Calculation of a quantitative assessment of the university management quality on solving a specific management problem.

This techniques can be used not only independently, but also to assess the management quality in order to achieve a certain strategic goal of the university development. For this reason, we call this assessment as a sub-index of university management quality (Index of University Management Quality - IUMQ), while the assessment of university management quality on achieving the strategic goal, which involves solving this problem, we name as Integral Index of University Management Quality (IIUMQ) ${ }^{4}$.

The calculation of the IUMQ sub-index is based on: 1) the chosen method of convolution of all indicators used to solve the problem; 2) considering the results of these indicators ranking (stage 3 of the algorithm). Consequently, with a linear convolution of the indicators selected at stage 2 and

\footnotetext{
2 The values of the indicator E.1 at St. Petersburg State University depend essentially on a specific department. Indicators E.2, E.3, and E.4 data on are not presented on the website of the university. The values of these indicators were chosen by the authors according to informal survey among full-time professors at the department of Information systems in economics for the 1st semester of 2018-2019 academic year.

${ }^{3}$ In St. Petersburg State University, as in most Russian higher education entities, the fringe benefits for the faculty include the statutory two-month paid leave, compulsory medical insurance and the option for voluntary medical insurance financed jointly by the University and teaching staff.

${ }^{4}$ The authors introduce the integral quality index, Integral Index of University Management Quality (IIUMQ), which no longer appears in this paper, for methodological reasons of the widespread use of this index in literature, as well as to apply the index in future studies.
} 
keeping in mind their ranking (stage 3 of the algorithm), the sub-index will be calculated by the formula:

$$
\begin{aligned}
I U M Q= & \frac{2}{5} \cdot E .1^{P}+\frac{3}{10} \cdot E .2^{P}+\frac{1}{5} \cdot E .3^{P}+\frac{1}{10} \cdot E .4^{P}= \\
& =\frac{2}{5} \cdot 2+\frac{3}{10} \cdot 2+\frac{1}{5} \cdot 6+\frac{1}{10} \cdot 3=2.9
\end{aligned}
$$

where $E .1^{P}, E .2^{P}, E .3^{P}, E .4^{P}$ - are point values of the indicators $E 1, E 2, E 3, E 4$.

Stage 7. Scaling of verbal and quantitative assessments of the quality of university management to solve a specific management problem. It assumes the construction of two interrelated scales that establish the correspondence between the interval score values of the sub-index and the verbal assessment of the quality of university management in solving a specific managerial problem (Table 4).

Table 4. Example of interrelated quality management scales for a higher education institution in solving a specific managerial problem

\begin{tabular}{|l|c|c|c|}
\hline $\begin{array}{c}\text { Scale of values of the verbal } \\
\text { assessment of the university } \\
\text { management quality on solving a } \\
\text { specific management problem }\end{array}$ & $\begin{array}{c}\text { The quality of } \\
\text { management is "bad" }\end{array}$ & $\begin{array}{c}\text { The quality of } \\
\text { management is } \\
\text { "satisfactory" }\end{array}$ & $\begin{array}{c}\text { The quality management } \\
\text { is "good" }\end{array}$ \\
\hline $\begin{array}{l}\text { Scale of the point interval values } \\
\text { sub-index (for example) }\end{array}$ & $\begin{array}{c}\text { From } 0 \text { to } 2 \\
{[0 ; 2]}\end{array}$ & $\begin{array}{c}\text { More than } 2 \text { up to } 8 \\
(2 ; 8]\end{array}$ & $\begin{array}{c}\text { More than } 8 \text { up to } 10 \\
(8 ; 10]\end{array}$ \\
\hline
\end{tabular}

Source: authors' calculations

Stage 8. Verbal assessment of the of university management quality in solving a specific managerial problem. Initially the interval of hitting the actual value of the sub-index (in points) in one or another interval of its values is determined (Table 5).

Table 5. Determination the verbal evaluation of the quality of university management value to

\begin{tabular}{|c|c|c|c|}
\hline $\begin{array}{l}\text { Scale of the verbal assessment values of } \\
\text { the university management quality on } \\
\text { solving a specific managerial problem }\end{array}$ & $\begin{array}{c}\text { The quality of } \\
\text { management is "bad" }\end{array}$ & $\begin{array}{c}\text { The quality } \\
\text { management } \\
\text { is "satisfactory" }\end{array}$ & $\begin{array}{l}\text { The quality } \\
\text { management } \\
\text { is "good" }\end{array}$ \\
\hline Scale of point interval values of sub-index & $\begin{array}{c}\text { from } 0 \text { to } 2 \\
{[0 ; 2]}\end{array}$ & $\begin{array}{c}\text { more than } 2 \text { up to } 8 \\
(2 ; 8]\end{array}$ & $\begin{array}{c}\text { more than } 8 \text { up to } 10 \\
(8 ; 10]\end{array}$ \\
\hline Actual value of the sub-index & & 6 & \\
\hline
\end{tabular}
solve the specific managerial task

Source: authors' calculations

Then, by the hit interval, the value of verbal assessment of the quality of university management on the solution of a specific managerial problem is determined. If the actual value of the sub-index calculated at stage 6 is 6 , and it falls within the range of values "more than 2 to 8 ", the verbal evaluation of the quality of management in this case takes the value "satisfactory". In the above calculation, the sub-index value is 6 . This corresponds to a satisfactory value of the verbal assessment.

\subsection{Illustration of the model application}

One of the advantages of the approach mentioned above is that it allows for meaningful international comparisons. The first systematic research on academic remuneration and contracts in 28 countries was published in 2012 (Altbach, 2012). This endeavor provided a solid theoretical 
foundation for further academic advances in the area by covering global faculty salaries, non-salaried ("social," or fringe) benefits, supplementary employment, and academic contracts. The average salary of university professors in Russia in 2002 was estimated at 617 \$ PPP, the lowest after Armenia (538). Corresponding figures for China (720), Kazakhstan (1,553), Latvia $(1,785)$, and Nigeria $(4,629)$ were higher than Russia's, not to mention several high-income economies such as the UK $(5,943)$, USA $(6,054)$, Italy $(6,955)$, and Canada $(7,196)$. Given the absence of tenure or civil servant status and modest fringe benefits, the level of professors' remuneration in Russia was hardly enough to maintain local middle-class living standards. The mentioned research hinted at the need to improve university programs, to support high-quality research, and to restore the prestige of the academic profession in Russia (Androushchak, Yudkevich, 2012, p.277). We regard this situation as evidence that acute problems exist both in the design of tertiary education and in the management of Russian universities. We also should mention a rapid increase of faculty salaries in Russia in the second half of 2000th and in the beginning years of 2010th. The figure for the Saint-Petersburg State University, Faculty of Economics in 2017, which is used for the further analysis, equals to 2203 \$ PPP, instead of the early mentioned 617 \$ PPP in 2002.

The model developed in the previous section of this paper can provide further insights into the issue of academic stuff remuneration and a management strategy for its improvement. For this purpose, it might be useful "to compare the incomparable" in order to draw a managerial roadmap, or at least to estimate the gap with the level of a world's best institutions. More specifically, we can apply to model for comparison across academic entities at radically different stages of development such as the Saint Petersburg State University (SPSU) and the University of California at Los Angeles (UCLA). We are fully aware that the SPSU has not reached the level of UCLA, which is one of the leading academic institutions in the world. At the same time, we compare a management quality rather than conditions for professors at two different universities. In this regard, the following assessment seems beneficial in illustrating our approach. The content of stages 1-4 of the algorithm is the same for both universities. The results of stage 5 are the scored actual values of the indicators used to assess the quality of management of both universities in solving the considered problem. The results are presented in Table 6.

Table 6. Actual values of indicators for the SPSU and the UCLA in 2017, used to calculate the sub-indices of the quality of university management for solving the problem of creating favorable conditions for university professors' hiring, work and academic contracts

\begin{tabular}{|l|c|c|c|c|}
\hline \multirow{2}{*}{} & \multicolumn{2}{|l|}{ The actual values in natural units } & \multicolumn{2}{c|}{$\begin{array}{c}\text { The actual values in point units } \\
\text { (E.iP) }\end{array}$} \\
\cline { 2 - 5 } & SPSU & UCLA $^{\mathbf{5}}$ & SPSU & UCLA \\
\hline $\begin{array}{l}\text { Guaranteed amount of monetary reward for } \\
\text { the month of the professor's work (E.1) }\end{array}$ & $\begin{array}{c}2,203 \\
\text { \$PPP }\end{array}$ & $\begin{array}{c}240,000 \\
\text { \$PPP }\end{array}$ & 2 & 9 \\
\hline $\begin{array}{l}\text { Guaranteed duration of the professor's } \\
\text { academic contract (E.2) }\end{array}$ & 2.0 & lifelong & 2 & 10 \\
\hline $\begin{array}{l}\text { The size of the professor's classroom load } \\
\text { (E.3), academic hours in a week on average, } \\
\text { annually }\end{array}$ & 8 & 4.5 & 6 & 9 \\
\hline $\begin{array}{l}\text { The level of social support ("social package") } \\
\text { of professors (E.4), points }\end{array}$ & 3 & 9 & 3 & 9 \\
\hline
\end{tabular}

\footnotetext{
${ }^{5}$ In UCLA, the value of E. 1 (monthly salary in international dollars, considering the 1.0 PPP conversion factor, provided by the World Bank, World Development Indicators) and the value of E.2 (the guaranteed duration of an academic contract) are for professors of the Faculty of Economics.

${ }^{6}$ In St. Petersburg State University, as in most Russian universities, only a legislatively established two-month paid leave, compulsory medical insurance and the ability to use voluntary medical insurance can be indicated as a fringe benefits of teaching staff, and for UCLA professors these benefits are much wider.
} 
In accordance with the algorithm step 6, the values of the sub-indexes were calculated according to the following equitation:

For SPSU: $\quad I U M Q(S P S U)=\frac{2}{5} \cdot 2+\frac{3}{10} \cdot 2+\frac{1}{5} \cdot 6+\frac{1}{10} \cdot 3=2.9$;

For UCLA: $\quad \operatorname{IUMQ}(U C L A)=\frac{2}{5} \cdot 9+\frac{3}{10} \cdot 10+\frac{1}{5} \cdot 9+\frac{1}{10} \cdot 9=9.3$

The implementation of stage 8 for both universities gives the following results. The IUMQ sub-index (SPSU), equal to 2.9, meets the satisfactory quality of management at SPSU in solving the problem of creating favorable conditions for hiring, work and academic contracts of university professors, and the IUMQ (UCLA) sub-index value, equal to 9.3, meets the good quality of UCLA management to solve this problem.

A comparative analysis of the obtained results makes it possible to draw the following conclusions:

$\checkmark$ conditions of hiring, work and academic contracts of university professors at UCLA are much more favorable and attractive than at SPSU;

$\checkmark$ the terms of employment, work, and academic contracts of university professors at UCLA are estimated as good;

$\checkmark$ the terms of employment, work and academic contracts of university professors at SPSU are estimated as bad;

$\checkmark \quad$ the most vulnerable and critical in terms of employment, work and academic contracts of professors at SPSU are the values of the guaranteed salary indicators and the duration of the academic contract.

Once again, with this comparison we are not saying that professors at the SPSU should receive the same remuneration as their colleagues in the UCLA. The point is that an inadequate level of salaries and fringe benefits can significantly weaken higher education institutions in Russia through an adverse selection of faculty members seeking additional income and reducing efforts on the main job, lower job satisfaction, and loss of productivity. These are purely managerial issues, and in this sense they should be properly addressed by university administration.

The provided illustration uses a narrow data set on conditions for professors' work, defined by university administration policy. At the same time, the developed methodology is general in nature and can be applied to other stages of management, such as planning, organizing, directing, coordinating, and controlling. We consider this application, as well as acquiring the reliable and comprehensive data, as a promising area for future research.

\section{Conclusions}

This study resulted in three helpful findings. First, the activities of an institution as complex as a modern university produce numerous interrelated effects that impose a profound influence upon multiple social factors. Despite the multifaceted interaction of variables, the constructed model provides an accurate analysis of the university characteristics and can be used to assess the quality of its management. Thus, the hypothesis that a single model can adequately evaluate overlapping effects was verified. The methods applied for compiling the balanced scorecard, ranking indicators, determining specific point values, conducting linear convolution, and calculating final indices confirm the validity and accuracy of the model.

Second, the model was tested using a relatively narrow data set, intent on creating a productive work environment for professors at two large universities. One university is a recognized leader in higher education and the other has a considerably lower reputation. The nature of the model and test results confirm the possibility of simultaneously evaluating and computing multiply variables within a single assessment. Therefore, a similar technique can be applied to processing different indicators that characterize the quality of university management on each of its stages. 
Third, the most promising method for implementing the model is to subject it to an environment that displays a large number of incomparable effects, arising from universitycommunity partnerships. Related activities rapidly transform the patterns of regional development in countries worldwide. The process can be particularly useful for East European and Eurasian states facing the challenge of provincial revitalization under worsening population outflow, tightening budget constraints and accelerating economic restructuring.

The application of the suggested model for assessing the quality of university management in light of its ability to predict the influence of diverse structural activities on multiple social factors, its success at yielding accurate results when applied to differing academic entities, and its applicability to local communities in transition represent promise for future research on this topic.

\section{References}

Adler, N.J., Harzing, A.W. (2009). When Knowledge Wins: Transcending the Sense and Nonsense of Academic Rankings. // Academy of Management Learning \& Education. 8(1): 72-95.

Ahamer, G. (2015). Quality assurance in transnational education management: The developmental "Global Studies" curriculum. Curriculum Design and Classroom Management: Concepts, Methodologies, Tools, and Applications. 3: 1271-1313.

Altbach, Ph.G., ed. (2012). Paying the professoriate: a global comparison of compensation and contracts. Routledge. 370 p.

Androushchak, G., Yudkevich, M. (2012). Russian Higher Education: Salaries and Contracts. In: Paying the professoriate: a global comparison of compensation and contracts. Ed. by Albach, Ph.G. Routledge. Pp.265-277.

Anglin, R. (2011). Promoting Sustainable Local and Community Economic Development. Taylor \& Francis, New York, USA. 275 p.

Balanced Scorecard (2018). Balanced Scorecard Review University of California, USA. Accessed December 13, 2019. - http://www.balancedscorecardreview.com/pages/bsc-inpractice/case-studies/university-of-california-united-states-103.html [2019 12 13].

Belov, A., Chernova, G., Khalin, V., Kuznetsova N. (2018). Universities' Competitiveness Models in Academic Management: a National-Level Approach // Management Theory and Studies for Rural Business and Infrastructure Development. 40(2): 155-166.

Belov, A., Zolotov, A. (2014). Socioeconomic Aspects Affecting University Education in Japan // Voprosy obrazovaniya (Educational Studies). Moscow. No 3: 30-53.

Biju, S., Nair, S.K. (2017). Measuring academic quality: A three-dimensional approach for internal audit using DMAIC // International Journal of Six Sigma and Competitive Advantage.10 (34): $236-257$.

Calderwood, P. E. (2000). Learning community: Finding common ground in difference. New York: Teachers College, Columbia University, USA. 168 p.

Carayannis, E. G., Campbell, D. F.J. (2009). 'Mode 3' and 'Quadruple Helix': toward a 21st century fractal innovation ecosystem. // International Journal of Technology Management. 46 (3/4): 201.

Cifuentes-Madrid, J.H., Couture, P. L.; Llinàs-Audet X. (2015). Strategic Management of Universities in the Ibero-America Region: A Comparative Perspective. Springer. 146 p.

Etzkowitz, H., Leydesdorff, L. (1995). The Triple Helix -- University-Industry-Government Relations: A Laboratory for Knowledge Based Economic Development. // EASST Review. 14: 1419.

Johnes, J. (2006). Data envelopment analysis and its application to the measurement of efficiency in higher education. // Economics of Education Review. 25 (3): 273-288. 
Galvao, A., Mascarenhas, C., Marques, C., Ferreira, J., Ratten, V. (2019). Triple helix and its evolution: a systematic literature review. // Journal of Science and Technology Policy Management. 10 (3): 812-833.

Jacob, W., Sutin, S., Weidman J., Yeager J. and others (2019). Community Engagement in Higher Education Policy Reforms and Practice. Sence Publishers, University of Pittsburgh, USA. 287 p.

Kaplan, R.S. and Norton, D.P. (1996). The Balanced Scorecard: Translating Strategy into Action. Boston: Harvard Business School Press. 322 p.

Khalin, V., Chernova, G. (2018). Models of University Formation - World Leaders. In: V. Khalin, ed., The global competitiveness of leading universities: models and methods for estimating and forecasting. Moscow: Prospekt. 24-89.

Khalin, V.G., Chernova, G.V. (2018). Development of a balanced scorecard for the quantitative assessment of the quality of management in leading Russian universities. Proceedings of the XXII International Scientific and Practical Conference "System Analysis in Design and Management”. St. Petersburg, Polytechnic University. Part 2: 299-309.

Liman, I.A. (2006). Higher education in Russia: problems of management and financing. Tyumen. Russia. 2006. 172 p.

Lassoued, K. (2018). Balanced scorecard implementation in higher education: An Emirati perspective. // Corporate Ownership \& Control. 15. 205-216.

Maslova, L.D., Gafforova, E.B. (2012). On systems for assessing the quality of higher education // International Scientific and Practical Journal. Issue 3: 63-69.

Ministry of Education, Culture, Sports, Science and Technology (MEXT), Japan (2019) Follow up Materials on Program for Promoting Regional Revitalization by Universities as Centers of Communities: COC + Program, in Japanese. - https://www.jsps.go.jp/jcoc/chukan_hyoka.html [2020 01 13].

Olssen, M., Peters, M.A. (2005). Neoliberalism, higher education and the knowledge economy: from the free market to knowledge capitalism. // Journal of Education Policy. 313- ): 3( 20 345.

Organization for Economic Co-operation and Development Organization for Economic Cooperation and Development (OECD) (2001). Cities and regions in the new learning economy. OECD, Paris, France.

Ozkan, S., Koseler, R. (2009). Multi-dimensional students' evaluation of e-learning systems in the higher education context: An empirical investigation. // Computers \& Education. 53 (4): 1285 1296.

Owlia, M.S., Aspinwall, E.M. (1996). Quality in higher education - A survey. // Total Quality Management. 7 (2): 161-171.

Pakhomova, N.V., Richter, K.K. (2013). University and the innovation challenge // University Management, Practice and Analisys. 1(83): 28-42.

Preece J. (2017) Community Engagement and Its Evolving Terminology. In: University Community Engagement and Lifelong Learning. Palgrave Macmillan, Cham. 214 p.

Richter K.K., Pakhomova N.V. (2012). University as a driver of innovation development // Vestnik. St.Petersburg University. 5 (4): 61-82.

Rosovsky, H. (2014). Research universities: American exceptionalism? // Carnegie Reporter. Winter 2014: 59-63.

Salmi, J., (2009). The challenge of establishing world class universities. The World Bank. 117 p.

Seema, R., Udam, M., Mattisen, H., Lauri, L. (2017). The perceived impact of external evaluation: the system, organisation and individual levels - Estonian case // Higher Education. 73 (1): $79-95$. 
Schuetze H.G. (2012). Universities and Their Communities-Engagement and Service as Primary Mission. In: McIlrath L., Lyons A., Munck R. (eds) Higher Education and Civic Engagement. Palgrave Macmillan, New York. 268 p.

UCLA (2019). Academic Ranking of World Universities. http://www.shanghairanking.com/ARWU2019.html [2020 05 07]

Vilgats, B., Heidmets, M. (2011). The impact of external quality assessment on universities: The Estonian experience // Higher Education Policy. 24 (3): 331-346.

Udam, M., Heidmets, M. (2013). Conflicting views on quality: Interpretations of 'a good university' by representatives of the state, the market and academia // Quality in Higher Education. 19 (2): 210-224.

Zimmerman, E. and others (2019). Assessing the Impacts and Ripple Effects of a Community-University Partnership: A Retrospective Roadmap // Michigan Journal of Community Service Learning. Winter 2019: 62-76. 